\title{
Snacking and Dietary Intake of Protein and Energy by High School Adolescents in Nairobi, Kenya
}

\author{
Catherine Muthoni Nguu-Gutu ${ }^{1,2}$, Prof. Jasper K. Imungi ${ }^{2}{ }^{3}$ \\ Dr. Edith M. Ngatia ${ }^{3}$ \\ ${ }^{1,2}$ Department of Human Nutrition and Dietetics, School of Health Sciences and Technology \\ Technical University of Kenya, P.O.Box 52428-00200 Nairobi, Kenya \\ ${ }^{2}$ Department of Food Science, Nutrition and Technology, College of Agriculture and Veterinary Services \\ University of Nairobi, Kenya \\ ${ }^{3}$ University of Nairobi, Department of Paediatric, Dentistry and Orthodontics, University of Nairobi, Kenya
}

\begin{abstract}
This was a cross-sectional, descriptive study Public National Boarding High schools in Nairobi ( $N=352$ students with 172 males, 180 females).The sample was systematically, randomly selected and allocated proportionately to both genders. This study aimed at assessing "snacking and dietary intake of protein and energy among high school adolescents". Quantitative data collected using a semi-structured questionnaire were analyzed using Statistical Package for Social Sciences (2007 SPSS inc.) version 16.0. Qualitative data were collected through focus group discussions, key informant interview, observations, Food frequency Questionnaires. Dietary intake data using 24-hr recall were analyzed using Nutri-survey. About $38.7 \%$ had inadequate protein intake where twice the number of females (25.8\%) than males (12.9\%) had lower RDA \% fulfillment of protein intake. More males (22.6\%) than females (19.4\%) had inadequate fat intake. Overall, $77.4 \%, 74.2 \% \quad 58 \%$ and $61.3 \%$ had taken adequate $(\geq 100 \%)$ RDA for carbohydrates, energy, fat and proteins respectively. There was insignificant difference between snacking and protein-energy adequacy ( $p>0.05)$ from school meals. Although snacking reduced students' consumption of regular school meals, it didn't affect their dietary intake. Healthy nutrient-rich snacks should be stocked in school canteens and their nutritional importance be raised. Snacks contribute substantially to students' total energy intake.
\end{abstract}

Keywords: Dietary intake, High school adolescents, Protein energy intake, School meals, snacking

\section{Introduction}

Snacking has become quite rampant in high schools where females snack more than males. Snacking is any intake of food or energy-containing beverage outside of the usual meal times (breakfast, lunch and dinner). These snacks can be savory like nuts, cheese, crisps, pretzels and breads; sweet like cakes, yoghurts, fruit, biscuits, chocolate and confectionery, and beverages like fruit juices, squashes, carbonated soft drinks or milk [1]. According to the World Health Organization adolescence is a stage of development which corresponds roughly to the ages between 10 and 19 years [2]. Adolescence is an important period during which major biological, social, physiological, and cognitive changes take place. Adolescents have special nutritional needs due to the rapid growth (lean body mass, fat mass, bone mineralization) and maturational changes associated with the onset of puberty. According to nutritional surveys carried out mostly in developed world, many adolescents do not meet dietary requirements for their age group due to inadequate dietary intake of energy and proteins [3]. Some adolescents have problems with dietary excesses resulting in overweight and obesity as well as dietary inadequacies resulting in underweight [4]. Under nutrition and many chronic diseases can delay the onset of puberty. Growth is not a continuous process, but proceeds as a series of small growth spurts that vary in amplitude and frequency. All these factors influence an individual adolescent's nutritional needs, food and snack choices which will vary between and within individuals overtime [5]. As the growth spurt begins, adolescents begin to eat more. They face many challenges as they pursue their independence, experience identity crises, seek peer acceptance, and worry about physical appearance, constantly being bombarded with a mixed message [6]. The media directs advertisements for high-fat and high-sugar foods and snacks at adolescents, while at the same time sells the importance of a perfect body. All these factors including peer pressure, increased hunger often dictates their food choices. Many schools that they attend offer fat-rich, highsugar snacks and soft drinks in their tuck shops. This in turn competes with school meals. Eating healthy is not always consistent with eating what is always popular. Adolescents rarely think about the long-term benefits of good health and have a hard time relating today's actions to tomorrow's health outcomes. Poor food choices and not snacking is the adolescents' problem [7].

According to [3], adolescents seem to adopt fad diets, and snack a lot. Adolescent females are very concerned with weight gain, appearance, and social acceptance. In an attempt to reach personal goals of gaining 
or losing weight, females may eat dangerously little, select a few items and frequently skip meals. Adolescents also have a common problem of having fat phobia [8]. If their limited food choices consist of French fries, sugar-sweetened soft drinks and pastries, only little room is left for school meals that are rich nutrient sources [9] [3], [10]. Adolescence is a time of rapid growth and development, which makes this a period of nutritional vulnerability. Adolescents also gain increased control over their own food choices and often acquire poor dietary patterns such as skipping breakfast and rely on eating fast foods or regularly eating meals outside the home or school [11]. These habits could translate into consumption of energy-dense or nutrient-poor diets that may potentially contribute to overweight.

According to [12], nutritional needs of adolescents are higher than those of children because of growth spurt, sexual maturation, changes in body composition, skeletal mineralization and changes in physical activity. This increases total energy needs due to the larger body size. Adolescent males and females differ in their nutritional needs due to their earlier maturation of females and the considerable variability of puberty and nutrient requirements [13] [14]. Nutrient needs are increased for protein, and energy. Little information exists about snacking by adolescents in schools, or how snacking may influence meal consumption. Previous studies have shown that snacking among adolescents is most common in the afternoon [15] [16]. This study focused on snacking and its association with dietary intakes of protein, and energy from school meals by adolescents in two National High schools.

\subsection{Statement of the problem}

Adolescence is a time of rapid growth and development, which makes this a period of nutritional vulnerability. It has been observed that there is usually a lot of snacking by adolescents especially in boarding schools but the level of snacking remains unknown. The extent of snacking depends on the socio-economic background and gender of the adolescent [6]. The snacking may involve unhealthy foods that may contribute insufficiently to nutrition [[9]. Snacking may reduce consumption of the nutritionally balanced meals served in schools or even act as replacements altogether. The level of snacking may affect the dietary intake from the school meals and therefore the nutritional status. Adolescents also gain increased control over their own food choices and often acquire poor dietary patterns such as skipping breakfast and relying on eating fast foods or regularly eating meals outside the home or school [11]. These habits could translate into consumption of energydense or nutrient-poor diets that may potentially contribute to overweight or underweight respectively [9].

\subsection{Justification and Contribution of the Study}

Continued negligence of adolescents in nutritional studies may impede the benefits already accrued from nutrition improvement for children under five years. Therefore, understanding how existing programs for adolescents reduce malnutrition risks and vulnerabilities, is the foundation for identifying the gaps that need to be addressed for the group aged 13-18 years, a group that is in transition from childhood to young adults. This age group was studied to maintain consistency with the life-stage groups established in the Dietary Reference Intake (DRI) reports [17]. A written informed consent was obtained from the school administration, if participants were younger than 18 years of age, and from the participants who were 18 years.

Good nutrition is the foundation of a healthy and strong nation. Based on this understanding, together with information on effect of snacking on dietary intake, it is important to undertake this research to find out whether snacking has an effect on dietary intake of proteins and energy from the normal school meals by high school adolescents in national boarding schools. This will help map-out appropriate intervention strategies for planning meals and stocking of school canteens as well as help in formulating nutrition policies and setting up nutrition education programmes for the High School students.

\subsection{Purpose of the Study}

The purpose of this study was to contribute new information on snacking and its effect on dietary intake of proteins and energy from school meals by high school adolescents.

\subsection{General Objective}

To assess the level of snacking in association with dietary intake of proteins and energy from school meals of high school adolescents aged 13-18 years in two national schools in Nairobi County, Kenya.

\section{Materials And Methods}

\subsection{Study Design, Sample Size Determination and Sampling Procedure}

A cross-sectional and descriptive study was conducted among adolescents aged 13-18 years in two public national boarding high schools in Nairobi Kenya. The two schools were purposively and randomly chosen as they are the true national schools as students are admitted from the whole country regardless of students' socio-economic background. Both qualitative and quantitative data were collected for descriptive and analytical analysis. Qualitative data were collected through Focus Group discussions (FGDs), Key informant 
interviews (KII) and personal observations. The population consisted of all adolescents attending National schools and the sampling frame comprised of all the adolescents attending the two schools studied.

Sample size was calculated using the Fishers' formula [18] based on the prevalence of underweight among the school going children aged 11-17 years in Nairobi County, which stands at 35.1\% [19] with an attrition allowance of $10 \%$ of the sample size. This gave a total of $\mathrm{N}=290$ although a larger sample size of $\mathrm{N}=357$ for ease of sampling procedures in the randomly selected schools.

A multistage cluster sampling, gender- and boarding-stratified sampling was used. The two public national boarding high schools were purposefully and randomly selected according to gender using elimination method [20]. Proportionate to size method (PPS) was used according to the number of streams and gender. Simple random sampling for the sample size was done from the compiled data from Ministry of Education (M.O.E) and class lists from the schools giving everyone an equal chance of being selected. Probability Proportionate to Size (PPS) method was used to select the sub-sample for the 24-hour recall dietary intake assessment of the population under study. Students from every class in each school were randomly selected giving a total of 36 students. However, five students were flagged off during data cleaning.

\subsection{Questionnaire}

A self-administered semi- structured questionnaire accompanied by an explanatory letter of transmittal (showing the purpose of the study, significance of the study, confidentiality), dully signed by the researcher and a consent form was delivered to the high school adolescent students through the school administration. This was used to collect information on socio-demographic characteristics (age, sex), snacking, dietary intake of protein and energy, anthropometry (height, weight), water intake, and personal hygiene. This was preferred over other instruments because it was easier to administer, analyze and economical to use in terms of time and money [21]. The questionnaire was pre-tested in the two National Public boarding secondary schools in Nairobi using students outside the selected sample group but with similar characteristics with the actual sample in the study. The pretest sample was approximately $8 \%$ (26) of the total sample size proportionately distributed in the two schools. Pre-testing results were used to modify the questionnaires before actual data collection thereby improving and enhancing their quality and reliability respectively.

\subsection{Food Frequency Questionnaire (FFG)}

FFQ according to [22] was used to collect qualitative data on the frequency of foods eaten, the levels, frequency and timing of snacking. It was also to determine dietary/food intake from the normal school meals. It established the frequency at which certain types of food (those of particular interest in the survey) were consumed over a specified time-frame normally a week or two or monthly. The foods were grouped into seven main food groups: fruits and vegeTABLEs; legumes; animal products; cereals; roots and tubers; oils and fats; sugars and snacks. Their frequency of consumption was coded as:

"Frequently consumed"- food item consumed once a week to many times a day.

"Not frequently consumed"- food item consumed no more than twice a month,

"Never-consumed"=food item not consumed at all.

\subsection{Key Interview Informants (KII)}

Eight KII comprising of cateress/caterer and cooks from the two schools were selected based on their knowledge on catering/ food production and service. A key informant interview guide was used to collect information on general cleanliness/hygiene of the kitchens, dining room and the environment, kitchen personnel, foods cooked (quality and quantity), meals eaten by students and food storage. A key informant interview guide was administered to the school cateresses and senior cooks from the two schools. Cateresses/caterer and cooks were the Key Informants selected on the basis of their knowledge on catering/ food production and service. It was used to collect information on general cleanliness/hygiene of the kitchen, dining room and the environment, kitchen personnel, foods cooked (quality and quantity) and meals eaten at school by the students, food storage, preparation and cooking methods, service, use of protective gear, water and sanitation.

\subsection{Focus Group Discussions (FGDs)}

A total of six FGDs (two from the females' school and four from males' school) each comprising of 12 to 14 members according to level, number of streams, and students per class in each school to avoid feelings of intimidation. Focus Group Discussions Guide was used to collect qualitative data on factors contributing to adolescents' divergent selection of foods, eating habits, and snacking while in the school. All the discussions were moderated by the principal investigator and information on factors contributing to their divergent selection of foods, eating habits, and snacking while in school recorded by research assistants. The FGDs were conducted in a free conducive discussion environment. A total of two FGDs from the females' school were held. Four FGDs from the males' school were conducted. This was because the junior classes (form $1 \& 2$ ) rarely mix with 
senior classes (form $3 \& 4$ ) as a tradition. Each FGD comprised of between 10 and 14 students. There were 14 Form ones from Nairobi school. Forms 2, 3, \& 4 formed three FGDs and each one of them comprised of 12 participants that is; 2 students per stream. All participants were picked by their respective class based on the most knowledgeable in the area. The Principal Investigator was the moderator in all the discussions as this required more skill. One research assistant was the observer while the other two took notes. The FGDs were conducted in a free atmosphere with members arranged in a circle for a conducive discussion environment. The proceedings of each discussion were recorded by the RAs. The information collected consisted of factors contributing to their divergent selection of foods, eating habits, and snacking while in the school.

\subsection{The 24-Hour Recall}

The 24-Hour Recall was used to determine the amount of food taken in the previous 24 hours and the ingredients contained in the meals. Liquid measuring cylinders of $5 \mathrm{ml}, 100 \mathrm{ml}$ and $1000 \mathrm{ml}$ were used.

This was used to determine the amount of food taken in the previous 24 hours. The ingredients contained in the meals were also listed. Liquid measuring cylinders of $5 \mathrm{ml}, 100 \mathrm{ml}$ and $1000 \mathrm{ml}$ were used. The 24 hour recall was conducted by the Principal Investigator assisted by two of the RAs since it required skill and previous experience. The data collected were then analyzed using the nutria- survey software. Intake of macronutrients (energy, carbohydrates, fats and proteins) in the last 24 hours by the students was established using a 24-hour recall on a sub-sample of 31 students. They were asked to list all the foods, drinks and snacks taken in the previous 24 hours. Using the Nutri-survey software, RDA percentage fulfillment of nutrient intake was established. By grouping the students by age and sex, the analyzed values were grouped into inadequate (less than $100 \%$ ) and greater than or equal to $100 \%$ RDA macro-nutrient fulfillment of energy, carbohydrates, fats and protein (TABLEs 13). In addition, food frequency from both school meals and snacks was assessed to find out the consumption of different food groups by all the students. The percent fulfillment of RDAs for macronutrients from dietary intake was established using a 24-hour recall, and further segregated by gender and age group. This is because the requirements for these nutrients differ according to gender and age of the individual. The means were required to determine the average adequacy of protein intake when considering the requirements per kilogram body weight per day.

\subsection{Anthropometric Measurements:}

A Checklist list of equipment and materials needed in the field was used to ensure that everything that was needed was available.

Height: The adolescents' height (with light clothing and without shoes) was determined using Standard Height boards (stadiometre) which were placed against a flat wall and on a flat surface. Two readings were taken each time and where the second height reading was found to have a wider variation $(+0.1 \mathrm{~cm})$, a third reading was taken. Height was recorded to the nearest 0.1 centimeters $(\mathrm{cm})$. Height-for-age (HAZs) z-score for was used for stunting [22].

Weight: Weight was taken using the electronic scale, whose battery was replaced every morning. The spring bathroom weighing scales were also used and were calibrated using a $2 \mathrm{~kg}$ packet of maize meal. Weights were taken with minimum clothing on (that is sweaters, jackets and shoes). Two readings were taken each time and where the second weight reading was found to have a wider variation (greater than +0.5 ), a third reading was taken. Only two closely related readings were recorded and average obtained. Weight was recorded to the nearest $0.1 \mathrm{~kg}$. The nutritional status of students was assessed as Body Mass Index (BMI)-for-age Percentiles (BAPs) for underweight, overweight and obesity [22].

\subsection{Recruitment of Research Assistants (RAs)}

This was advertised verbally and through friends. All the 17 RAs were year 2 and 3 Diploma students in Nutrition and Dietetics from Kenya Polytechnic University College with good written and oral communication skills. These were experienced in anthropometric data collection. Written and oral interviews were conducted and trained for two days by the Principal Investigator. The training program covered the background, statement of the problem, purpose and the objectives of the study, ethical issues, methods of interaction with the respondents, understanding and use of the questionnaire, data collection techniques and use of the checklists, how to use anthropometric equipment, taking and recording of the anthropometric measurements correctly.

\subsection{Inclusion and Exclusion Criteria}

Only those high school adolescent students aged 13 to 18 years were included. Those who were unwilling to participate in the interview were excluded and replaced with those from the same sex and age. Those with chronic illnesses were also excluded from this study. 


\subsection{Data Quality Control and Assurance}

Formulated easy-to-understand, clear questions were verified through pretesting to ensure their relevance and reliability. Beneficial amendments were made before leaving the field. Anthropometric measuring equipment was calibrated to zero every morning to ensure accuracy. Dietary intake data using a 24-hour recall was analyzed Nutri-Survey. Statistical analyses performed include: Descriptive statistics (measures of central tendency i.e. mean, median, mode; and measures of dispersion i.e. range, SD, variance for describing the different indicators that were applied; Chi square tests were used to determine whether associations between variables were significant or not. Socio-demographic data were correlated with snacking levels and frequencies, dietary intake (24hour recall) to establish if there was any relationship. Data from FGDs were analyzed to make baseline information about snacking levels and frequencies by the adolescent students, eating habits and factors influencing their food and snack choices. For Analytical statistics, cross tabulations between all categorical variables, dietary intakes of energy and protein were performed. The variables from the student's socio-demographic profile, levels and frequencies of snacking, dietary intake of proteins and energy were analyzed to establish how they influenced the adolescents' dietary intake relating it to the UNICEF'S (1998) conceptual framework for malnutrition. Data collected, and analyzed were presented using TABLEs, and bargraphs.

\subsection{Ethical and Human Rights Considerations}

Both written and verbal consent were given by the school administration and all the willing participants. The researcher familiarized all participants on the objectives of the study before they could make decisions about their involvement. All the participants were assured of confidentiality of any information collected from them and that throughout the research process, privacy, respect and dignity of all respondents was upheld.

\subsection{Socio-Economic Status of Families of the Students}

\section{Results And Discussions}

\subsubsection{Distribution of the Adolescents by Province}

Out of the sampled population of 352 adolescents students, Nairobi county recorded the highest representation at $(26.7 \%)$ followed closely by Rift Valley $(24.1 \%)$ and Eastern $(10.5 \%)$ respectively. North Eastern (2.0\%), Western (6.5\%) and Nyanza (7.7\%) Counties had the lowest admissions respectively. There were more females from Nairobi (13.9\%), Central (6.0\%), and Rift Valley (13.1\%) as compared to males from Nairobi (12.8\%), Central (3.7\%), Rift Valley (11.0) admitted to national schools.

\subsubsection{Distribution of the Respondents by Age}

The ages of the students ranged between 13 and 18 years; with a mean age of 15.8 (SD=1.399; variance $=1.956$ ). The mean age for females was 15.9 years, while that for males was 15.70 . There was no significant difference between the mean age of the males and females ( $p>0.5)$.

\subsubsection{Socio-Economic Status of the Households}

The socio-economic status of the respondents' families was presumed to influence the level of snacking. The socio-economic status of the students was determined using the occupation of the parents, their property ownership and the pocket money given to them.

\subsubsection{Parental status: Respondents by living and missing parents}

The results established that $88.5 \%$ of the students had both parents alive, while $2.6 \%$ had mother deceased, $7.4 \%$ had father deceased and $1.5 \%$ had both parents deceased. The students who had both parents deceased were being taken care of by guardians who included brothers, aunts, uncles or grandparents.

\subsubsection{Occupation of the parent/guardian}

Table 1: Occupation of parent/guardian

\begin{tabular}{|c|c|c|c|c|c|c|}
\hline Occupation & $\begin{array}{c}\text { Males } \\
\text { n }\end{array}$ & \multicolumn{3}{|c|}{ Females } & \multicolumn{2}{|c|}{$\begin{array}{l}\text { Total \& percent within } \\
\text { sample } \\
\text { n=348 \% }\end{array}$} \\
\hline Formal employment & 114 & 32.8 & 106 & 30.5 & 220 & 63.2 \\
\hline Self-employment & 30 & 8.6 & 38 & 10.9 & 68 & 19.5 \\
\hline Unemployment & 13 & 3.7 & 9 & 2.6 & 22 & 6.3 \\
\hline Farmer & 8 & 2.3 & 7 & 2.0 & 15 & 4.3 \\
\hline Housewife & 5 & 1.4 & 4 & 1.2 & 9 & 2.6 \\
\hline Casual & 5 & 1.4 & 4 & 1.2 & 9 & 2.6 \\
\hline Pensions & 3 & 0.8 & 1 & 0.3 & 4 & 1.2 \\
\hline Student & 0 & 0.0 & 1 & 0.3 & 1 & 0.3 \\
\hline Total & 178 & 1.1 & 170 & 48.9 & 348 & 100.00 \\
\hline
\end{tabular}


Table 1 shows the distribution of parents by occupation as this determines the amount of income available for family members, in turn influences their eating habits. Students whose parents had formal employment were $32 \%$ for males, $30 \%$ for females giving a total of $63.2 \%$ of parents in formal employment with regular income. Most parents/guardians obtained their income from self- $(19.5 \%)$ and formal employment $(63.2 \%)$ and that only $4.3 \%$ of the parents were farmers, although their level of farming was not indicated.

Those in formal employment are considered to be of HSES, considering that their salary is regular; while those self employed in small and medium enterprises (SMEs) were categorized as of middle socioeconomic status (MSES). On the other hand, those unemployed, pensioners, farmers, housewives, casual laborers and students were considered to be of low level income as their income was not regular and may vary from time to time. They may therefore not meet the nutritional needs of the respondents adequately, given the fact that these adolescents may not get adequate pocket money to afford snacking while in school. Parents in formal employment could positively influence the eating habits of the adolescents as well as the amount of pocket money given. In this county, we have three socio-economic classes, the high, the middle and the low. Currently, the low socio-economic status (LSES) families form the majority (51.2\%) of the population [23].

\subsubsection{Property ownership and Socio-economic statuses of the respondents' families}

Families that owned vehicles, land, DSTV, Game boy and Ipod were categorized under high socioeconomic status (HSES), Television, motorcycle, DVD player, play station under middle socio-economic status (MSES), and those who owned cell phone, radio, cart and bicycle were categorized under low socio-economic status (LSES). Table 2 shows that majority $(65.1 \%)$ of the families were from middle socio-economic status and $31.5 \%$ from LSES while only a small proportion $(3.4 \%)$ was from the HSES. Slightly more males $(33.5 \%)$ than females $(31.5 \%)$ are from families of MSES. Almost equal proportions of both males (16.6\%) and females (15.9\%) came from LSES. Both males and females come from almost similar socio-economic backgrounds with more males $(33.5 \%)$ than females (31.5\%) slightly leaning towards MSES and more females (15.9\%) than males $(15.6 \%)$ towards LSES.

Table 2: Socio-economic statuses of the respondents' families

\begin{tabular}{|c|c|c|c|c|c|c|}
\hline \multirow[t]{2}{*}{$\begin{array}{l}\text { Socio-Economic } \\
\text { Status }\end{array}$} & \multicolumn{2}{|c|}{ Males } & \multicolumn{2}{|c|}{ Females } & \multicolumn{2}{|c|}{ frequency } \\
\hline & & $(\%)$ & & $(\%)$ & n & $(\%)$ \\
\hline HSES & 7 & 2.0 & 5 & 1.4 & 12 & 3.4 \\
\hline MSES & 118 & 33.5 & 111 & 31.5 & 229 & 65.1 \\
\hline LSES & 55 & 15.6 & 56 & 15.9 & 111 & 31.5 \\
\hline Total & 180 & 51 & 172 & 48.9 & 352 & 100 \\
\hline
\end{tabular}

\subsection{Level of Snacking}

The level of snacking among the adolescents was established by finding out which gender snacked most, time of snacking, source of snacks, types of snacks eaten, and pocket money given, days of the week when they snack most.

\subsubsection{Snacking Characteristics of the Respondents}

3.2.1.1 Snacking by gender

Study shows that out of 352 sampled students, a total of $92.1 \%$ indicated snacking, with a slightly higher number of males $(91.4 \%)$ than females $(90.7 \%)$ snacking.

\subsubsection{Time of snacking}

Table 4 shows, majority (43.1\%) of the males snacked during the morning break, while most $(54.1 \%)$ of the females snacked during the afternoon. According to TABLE 5, more males than females snacked during break time, while majority of the females snacked in the afternoon and just before supper. This could probably be explained by the fact that males' canteen was open throughout the day, while the girl's canteen was only open at certain specific times in the evening just before supper. It was also observed that females are provided a bun and drinking chocolate during the 10 'clock tea break but not the males. This may explain why more males than females snack in the morning. 
Table 4: Time of Snacking

\begin{tabular}{|c|c|c|c|c|}
\hline \multirow[t]{2}{*}{ Snacking time } & \multicolumn{2}{|c|}{ Males } & \multicolumn{2}{|c|}{ Females } \\
\hline & $\mathrm{n}$ & $\%$ & $\mathrm{n}$ & $\%$ \\
\hline Morning & 3 & 1.9 & 2 & 1.3 \\
\hline Break time & 69 & 43.1 & 15 & 9.6 \\
\hline Just before lunch & 7 & 4.4 & 0 & 0.0 \\
\hline Afternoon & 54 & 33.8 & 85 & 54.1 \\
\hline Just before supper & 14 & 8.8 & 34 & 21.7 \\
\hline After supper & 13 & 8.1 & 21 & 13.4 \\
\hline Total & 160 & 100 & 157 & 100 \\
\hline
\end{tabular}

\subsubsection{Source of Snacks}

Table 5 shows that majority (79\% males and 95\% females) of the students from both schools obtained their snacks from the school canteens. Snacks are given by the schools occasionally to individuals as reward for good academic performance or to groups winning events in competitions of co-curricular activities like sports, games and athletics and during public holidays. This is seen as a way of motivating students to excel. These snacks (scones, mandazi and biscuits) are very popular among students.

Table 5: Source of snacks

\begin{tabular}{|c|c|c|c|c|}
\hline \multirow[t]{2}{*}{ Source of snacks } & \multirow{2}{*}{$\begin{array}{c}\text { Males } \\
\mathrm{n}\end{array}$} & \multicolumn{3}{|c|}{ Females } \\
\hline & & $\%$ & $\mathrm{n}$ & $\%$ \\
\hline School canteen & 124 & 79.0 & 151 & 95.0 \\
\hline Brought from home & 21 & 13.4 & 2 & 1.3 \\
\hline Given by school & 0 & 0 & 4 & 2.5 \\
\hline Friends & 1 & 0.6 & 2 & 1.3 \\
\hline Kiosks outside school & 2 & 1.3 & 0 & 0 \\
\hline Supermarket & 9 & 5.7 & 0 & 0 \\
\hline Total & 157 & 100 & 159 & 100 \\
\hline
\end{tabular}

\subsubsection{Snacking by Socio-Economic Status of Families}

According to Table 6, out of the total students (315) who were snacking, twelve students (3.8\%) came from high SES, 213 students (67.6\%) from middle SES and 90 (28.6\%)were from low SES. There was a significant difference between snacking among those from high socio-economic status as compared to those from middle and low socio-economic status $\left(\chi^{2}=11.896, \mathrm{P}\right.$ value $\left.=0.003\right)$. The higher the socio-economic status, the more the students were snacking and vice versa. The more the pocket money given, the more the students were snacking. However, all students (100\%) from high SES snacked. About $45.7 \%$ of the students snacked just because money was available. There was no significant difference in snacking between those students from low SES and those from Middle SES $\left(\chi^{2}=0.375, \mathrm{P}\right.$ value 0.829$)$. Snacking took place regardless of the S.E.S.

Table 6: Distribution of Snacking by Socio-Economic Status of Families

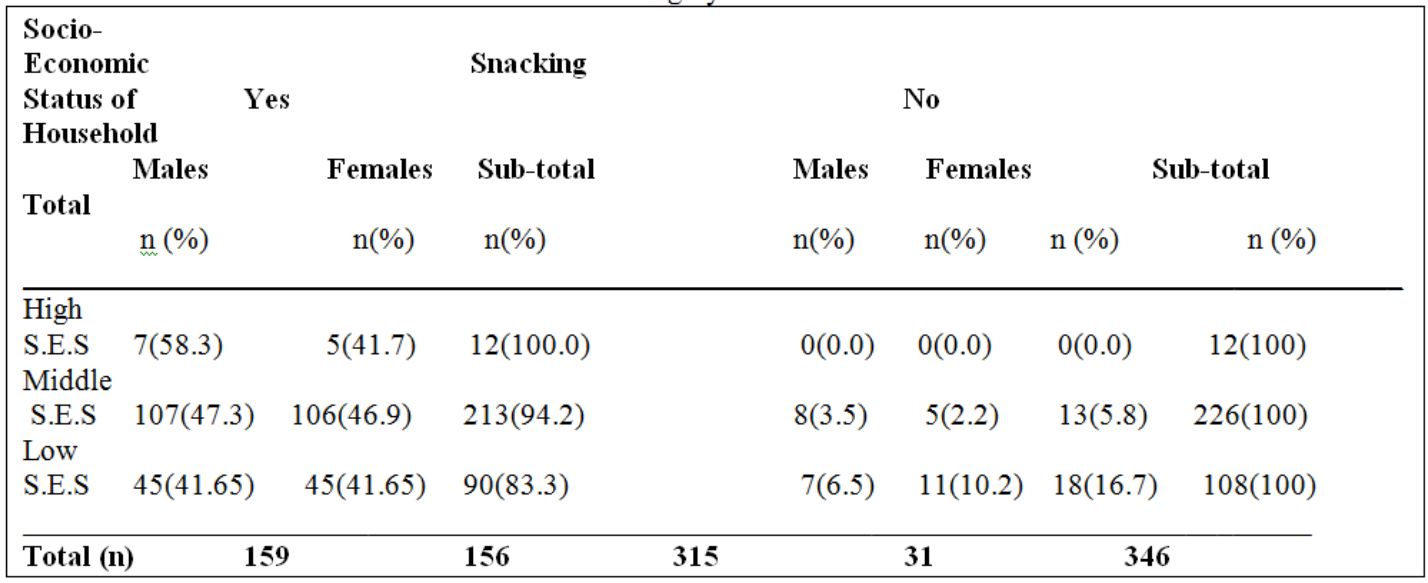

NB: Percentages are in parenthesis 


\subsubsection{Pocket money given and spending according to gender}

According to Fig. 1, the study established that all females were given pocket money. About $6 \%$ of males, majority of who were orphans, were not given any pocket money. The amount of pocket money given ranged from Ksh50-12,000. Majority of the students received money at the beginning of the term and during mid-term break (females $49.1 \%$ and males $47.3 \%$ ), and only at the beginning of the term (males $43.8 \%$, females $36.8 \%$ ). More than half of the males $(57.3 \%)$ were given Ksh1000 or less, while $42.8 \%$ females were given the same amount. Significantly more males (32\%) than females (41.5\%) were given more than Ksh 3,000. Only a small percentage of males $(2.0 \%)$ and females (1.9\%) were given more than Ksh 5,000. It was established that snacking by the students took place regardless of their SES.

\section{Amount of pocket money given to students}

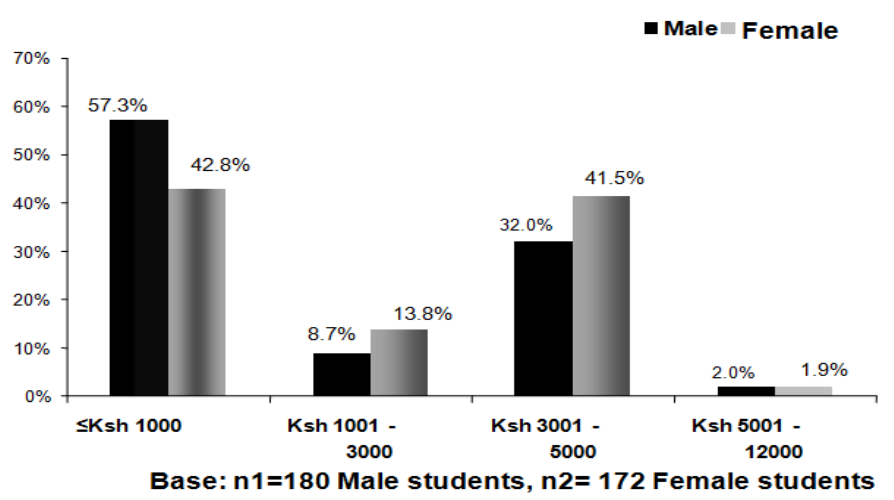

Fig. 1: Amounts of pocket money given to the students

Fig. 2 indicates that on average, majority $(68.6 \%)$ of the students spent their pocket money on snacks. More females (74.5\%) than males (62.7\%) spent their pocket money on snacks. Most females spend their pocket money on snacks than on any other use. This was followed by clubs (males $24.7 \%$, females $9.0 \%$ ). Only a small proportion (1.9\% males and $1.4 \%$ females) spent the money on buying books and other stationeries. The rest was either saved, spent on transport, buying clothes and/or other personal effects. More females (6.9\%) than males $(3.8 \%)$ saved some of their pocket money.

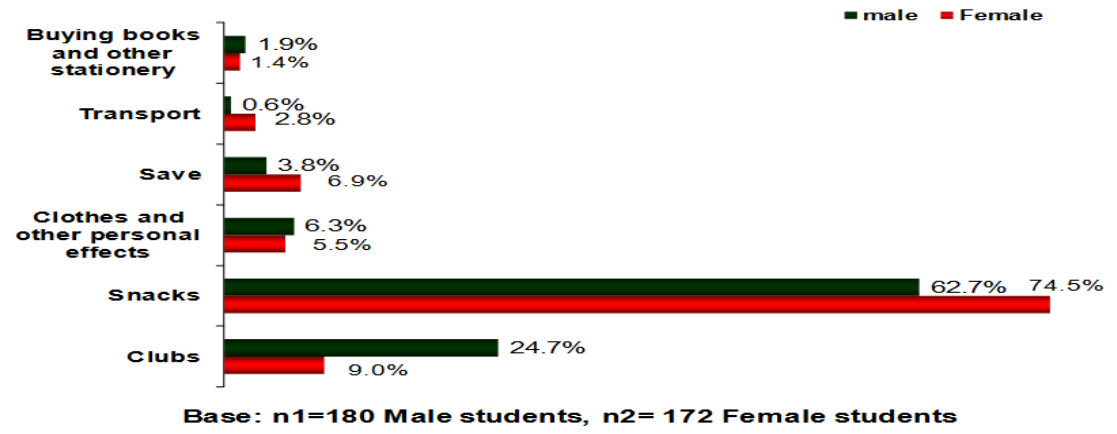

Fig. 2: Distribution of pocket money spending by sex of respondents

\subsubsection{Types of Snacks Available in the Schools}

Table 7: Distribution of snacks stocked at the school canteens

\begin{tabular}{|c|c|c|c|c|c|}
\hline Snack description & Males & Females & Unit of sale(gm) & Unit of sale (mls) & Price/ unit Ksh \\
\hline Andazi & * & - & 35 & & 5 \\
\hline Chapatti & * & - & 80 & & 10 \\
\hline $\begin{array}{l}\text { Biscuits (Manji, Nuvita, sunbix, short } \\
\text { cake) } \\
\text { Small packet } \\
\text { Medium packet } \\
\text { large packet }\end{array}$ & $\begin{array}{l}* \\
* \\
*\end{array}$ & $\begin{array}{l}* \\
* \\
*\end{array}$ & $\begin{array}{l}25 \\
50 \\
100\end{array}$ & & $\begin{array}{l}5 \\
25 \\
50\end{array}$ \\
\hline $\begin{array}{l}\text { Masala sticks (potatoes cut into thin } \\
\text { sticks and deepfried) }\end{array}$ & - & * & 50 & & 25 \\
\hline $\begin{array}{l}\text { lookies(cinnamon, chocolate, ginger, } \\
\text { melting) }\end{array}$ & - & * & 50 & & 50 \\
\hline Chocolate bar & - & * & 20 & & 30 \\
\hline Roxy chocolate & - & * & 14 & & 30 \\
\hline
\end{tabular}


Snacking and Dietary Intake of Protein and Energy by High School Adolescents in Nairobi, Kenya

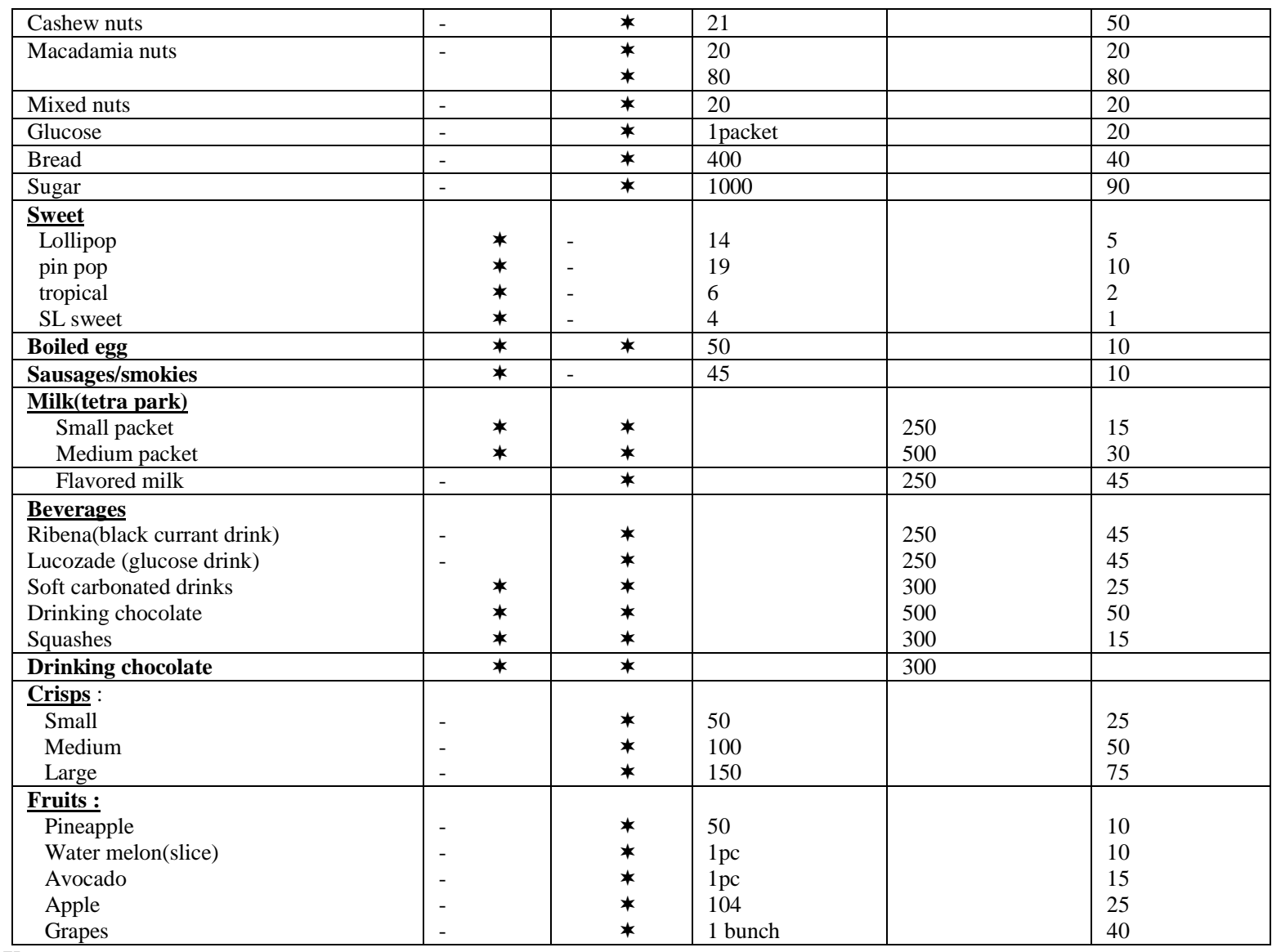

\section{Kev:}

* consumed;- not consumed;

Table 7 shows the different kinds of snacks available in the canteens of the two schools. The females' school offered a wider variety of snacks than the males' school. Healthier snacks were available in the females' school canteen in form of fruits and nuts, but not found in males' school canteen. The males' canteen contained more of the prepared snacks such as smokies/sausages, chapatti (from refined wheat flour) and mandazi.

\subsubsection{Snack Consumption According to Type of Nutrient}

Table 8 shows the snack items consumed which were placed into five major categories according to the type of nutrients they provide. 1) Carbohydrates/fat snacks included mandazi, biscuits, cookies, potato sticks, bread, chapatti, potato crisps, cakes, glucose, bites, buns, French fries, sweets, nuts, pop corn, doughnuts and chocolate bars; 2) Protein snacks included sausages/smokies, milk and ice cream; 3) Fruits included apple, mango, avocado, bananas and water melon; 4) Beverages such as drinking chocolate, tea and coffee were available; 5) carbonated soft drinks included commercial juices and cordials, sodas, lucozade (carbonated glucose solution) and ribena (black currant drink). No vegetable snacks were stocked in the school canteens. The females' school had a few fruits stocked in the canteen. They were not popular (1.1\%), may be because they were expensive. There was a very high snacking level during midterm, opening day because students brought snacks from home and during "githeri" and "ugali" meal times. This can be explained by the fact that school meals are not compulsory.

Snacks providing starches and fats were consumed by most (58.3\%) of the students, whereby more females $(37.2 \%)$ than males $(21.1 \%)$ were found to snack on starches probably because they were provided at the school canteen. However, more males snacked on proteins $(5.4 \%)$ than females $(1.6 \%)$. This could be because milk and sausages were sold in the males' school canteen which was open throughout the day both during weekdays and weekends. The Females' school canteen was open between $5.30 \mathrm{pm}$ to $6.00 \mathrm{pm}$ on weekdays and a few hours during weekends. The females indicated that there was no need to snack fruits because they were provided with the school meals. The males indicated that there were not available in the school canteen, moreover, in the FGD, they requested fruits be provided with school meals. 
Table 8: Categories of snacks consumed by type of nutrient

\begin{tabular}{|c|c|c|c|c|c|c|}
\hline \multirow[t]{2}{*}{ Group of snacks eaten a Male } & \multicolumn{4}{|c|}{ Females } & \multicolumn{2}{|c|}{ Total $(\mathrm{N}=1591)$} \\
\hline & Mean & $(\%)$ & Mean & $(\%)$ & Mean & $(\%)$ \\
\hline Carbohydrates/fats (g) & 335 & $(21.1)$ & 593 & $(37.2)$ & 928 & 58.3 \\
\hline Protein snacks $(\mathrm{g})$ & 86 & $(5.4)$ & 26 & $(1.6)$ & 112 & 7.0 \\
\hline Fruits (g) & 6 & $(0.37)$ & 12 & $(0.75)$ & 18 & 1.1 \\
\hline Beverages (ml) & 180 & (11.3) & 172 & $(10.8)$ & 181 & 22.2 \\
\hline Carbonated soft drinks (ml) & 92 & $(5.8)$ & 89 & $(5.6)$ & 352 & 11.4 \\
\hline
\end{tabular}

${ }^{a}$ Multiple responses allowed. Percentages and totals are based on respondents

\subsubsection{Means of Snack Quantities Consumed}

The students provided information on the amounts of snacks taken (in grams for solids or milliliters for fluids), either by stating the actual weight/volume or by indicating the cost of the snack. A market survey in the school canteens was done to establish the quantities of the said snacks.

Table 9: Means of Snack Quantities Consumed

\begin{tabular}{|lll|}
\hline $\begin{array}{l}\text { Mean quantities } \\
\text { Consumed }\end{array}$ & $\begin{array}{c}\text { Males (n=297) } \\
\text { Mean (SD) }\end{array}$ & $\begin{array}{c}\text { Females (n=344) } \\
\text { Mean (SD) }\end{array}$ \\
\hline $\begin{array}{l}\text { Mean quantities } \\
\begin{array}{l}\text { Solid snack (g) } \\
\text { Mean quantities }\end{array}\end{array}$ & $170.3 \pm 152.28$ & $206.8 \pm 188.29$ \\
Fluid snack (m) & $501.1 \pm 287.8$ & $249.85 \quad \pm 270.07$ \\
\hline
\end{tabular}

Table 9 shows that there was great variation in the quantities consumed by the students. Solids consumed were between $5 \mathrm{~g}$ and $1835 \mathrm{~g}$ with a mean of $202.37 \mathrm{~g}$, while quantities of fluid snacks ranged between $300 \mathrm{ml}-1890 \mathrm{mls}$ with a mean of $517.63 \mathrm{ml}$. The mean consumption of solid snacks by females $(206.8 \mathrm{~g} \pm 188.29)$ was higher than that of the males (170.3g). On the other hand, males consumed more liquids $($ mean $=501.1 \mathrm{ml} \pm 287.8)$ than females $($ mean $=249.9 \mathrm{ml} \pm 270.07)$. This is probably because the school canteen was operational throughout the day and that more liquid snacks were stocked in the males' canteen.

It was noted that both Form 1 and 2 students consumed slightly lower quantities of solids (mean= 410g) than their senior counterparts (Form 3 and 4 classes) who had a mean of $419 \mathrm{~g}$. There was however, a different trend with beverages, where the juniors (Forms 1 and 2) had taken relatively larger amounts, with a mean of $1043 \mathrm{ml}$ than the seniors (Forms 3 and 4 ) with a mean of $1015 \mathrm{ml}$.

\subsubsection{Snacks Consumed and Amount Compared To Pocket Money}

Table 10 shows that the amount of pocket money given varied considerably. It also indicates that over half of the males $(57.3 \%$ ) were given Ksh1000 or less, while $32.0 \%$ of males were given between ksh 3000 and ksh 5000. Majority of the females (42.8\%) were given more or equal to Ksh1000 and 41.5\% between ksh 3000 and ksh 5000. Students with Ksh1000 or less were found to consume more starches as compared to other snacks. This could be explained by the fact that most carbohydrate snacks are generally cheaper compared to others such as protein snacks, and fruits. Carbohydrate snacks also have a satiety value when compared to other types.

Table 10: Mean Distribution of Snack Consumption by Amount of Pocket Money

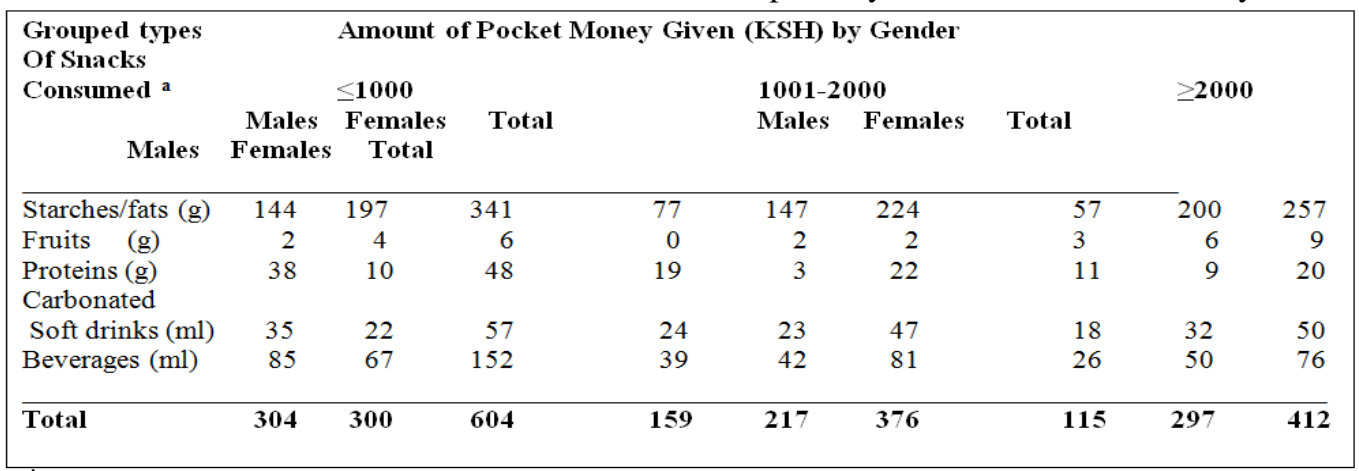

${ }^{a}$ multiple responses allowed 


\subsection{Dietary Intake from School Meals \\ 3.3.1 School Meal Schedules}

The food intake from the normal school meals clearly shows a balanced distribution of meals. However the adequacy of the food and the nutrient content was established during the study. Each school offered 3 meals and one snack, whereby the females received some plain cocoa drink and one bun in the mid-morning break while males received only plain cocoa as a mid-afternoon snack. The females' meals were better in providing a variety of food items in a single meal, than the meals for males. The Males' school catered for vegetarians by providing cabbage as a substitute for beef (which was not a perfect substitute as it could not provide the protein they missed from beef). This was also done to cater for those who did not take beans. This may probably explain why males snacked most in the morning while females snacked most in the afternoon just before supper as in Table 5. The males meals consisted of Breakfast (tea, 3 slices of bread and an egg on sundays), Lunch (cooked rice with either bean or green gram stew; Githeri-a mixture of beans and maize, a fruit once a week), Supper (Ugali-a mixture of water and maize meal cooked to a thick consistency served with beef stew and cabbage thrice a week; rice with bean or green gram stew four times a week). The females' meals consisted of Breakfast (tea with milk, 2 slices of buttered bread, 1 boiled egg and a smokie once a week); Lunch (Githeri served with steamed cabbage and carrots thrice a week, rice with bean stew, a banana thrice a week); Supper (Ugali served with beef stew and steamed kales or spinach, rice served with bean or green grams stew and steamed cabbage); evening snack ( 1 slice of buttered bread and tea).

\subsubsection{Food Frequency Recall}

Table 11 shows a summary of the different food categories and snacks consumed. It was found out that the food types frequently consumed (taken between 1-7 days per week) by majority were oils and fats $(35.2 \%)$, specifically margarine and cooking oil. carbonated drinks and/ or stillroom beverages (45.7\%) and cereals (48.7\%). The least consumed were vegetable and fruits (19\%) such as apples and oranges. Most consumed fruit was banana. While the most consumed legumes were beans (80.7\%) in form of bean stew or "Githeri'. Incidentally bean stew was the most liked by both genders. Among the animal products, meat was frequently consumed. Eggs were consumed once a week (77.3\%) while Milk was frequently consumed (36.5\%). The least consumed or never consumed animal products were poultry (48.4\%), yoghurt (82.3\%); fish $(85.2 \%)$, and sour milk $(89.2 \%)$ while frequently consumed cereals were rice $(88.1 \%)$, bread $(84.2 \%)$ ugali $(74.2 \%)$, and maize (59.4\%). Sweet potatoes were the least consumed. Between $20 \%$ and $30 \%$ of the adolescents students consumed biscuits/cookies and sodas between 1 to 7 days a week. Chocolates, sweets, and soft drinks especially sodas were mostly consumed once a month or twice a fortnight. Other snacks frequently consumed were potato crisps, (32.3\%). Tea and coffee were most consumed all the days of the week. This is in tandem with a research conducted by [24] on how snacking patterns influence energy and nutrient intakes. The frequent intake of oils and fats can be explained by the fact that margarine was given to students especially the females' school with buttered bread while fats and oils were used for the school meal preparations; chapatti, mandazi and other carbohydrate and sugary snacks were available especially in the males' canteen, hence the high percentage of oil consumption. This trend could be explained by the fact that those not frequently consumed are not provided in the school meals or in the school canteen. Those foods which were never or not frequently consumed were definitely because they were not included in the already predetermined school menus while some foods like fruits are quite expensive commodities hence not affordable and were not stocked in the canteens particularly for males. Only those fruits and vegetable provided in the school meals such as bananas were frequently consumed.

Table 11: Food Frequency from School Meals and Snacks by Food Category

\begin{tabular}{|c|c|c|c|c|c|}
\hline \multirow[t]{2}{*}{$\begin{array}{l}\text { Food } \\
\text { Type }\end{array}$} & \multirow{2}{*}{$\begin{array}{l}\text { Never } \\
\text { Consumed } \\
(\%)\end{array}$} & \multicolumn{2}{|c|}{$\begin{array}{l}\text { Not Frequently } \\
\text { Consumed }\end{array}$} & \multicolumn{2}{|l|}{$\begin{array}{l}\text { Frequently } \\
\text { Consumed }\end{array}$} \\
\hline & & $\begin{array}{l}\text { Once a } \\
\text { Month } \\
(\%)\end{array}$ & $\begin{array}{l}\text { Once a } \\
\text { Fortnight } \\
(\%)\end{array}$ & $\begin{array}{l}1-7 \text { Days } \\
\text { per Week } \\
(\%)\end{array}$ & $\begin{array}{l}\text { Total } \\
(\%)\end{array}$ \\
\hline $\begin{array}{l}\text { Fruits \& } \\
\text { VegeTABLEs }(N=7835)\end{array}$ & 70.6 & 7.8 & 2.6 & 19.0 & 100 \\
\hline Legumes $(N=1549)$ & 64.7 & 5.3 & 3.5 & 26.5 & 100 \\
\hline $\begin{array}{l}\text { Animal } \\
\text { Products }(N=1232)\end{array}$ & 50.2 & 15.6 & 4.6 & 29.6 & 100 \\
\hline Cereals $(N=\mathbf{2 4 2 3})$ & 44.6 & 4.4 & 2.4 & 48.7 & 100 \\
\hline $\begin{array}{l}\text { Root \& } \\
\text { Tubers }(N=594)\end{array}$ & 62.5 & 6.6 & 2.2 & 28.8 & 100 \\
\hline Oils \& fats $(N=1200)$ & 59.6 & 3.8 & 1.4 & 35.2 & 100 \\
\hline $\begin{array}{l}\text { Sugars\& } \\
\text { Snacks }(N=4534)\end{array}$ & 67.4 & 14.2 & 4.1 & 14.3 & 100 \\
\hline $\begin{array}{l}\text { Stillroom } \\
\text { Beverages }(N=634)\end{array}$ & 52.1 & 1.3 & 0.9 & 45.7 & Actiogt \\
\hline
\end{tabular}

${ }^{a}$ multiple responses allowed 


\subsubsection{Effect of Snacking on School Meals Consumption}

Table 12 shows that majority of the students took snacks and also ate the normal school meals. It was found that $68.8 \%$ of the students who consumed three normal school meals also ate snacks, while $22.1 \%$ took snacks and consumed less than 3 school meals. There was no significant $(\mathrm{P}$-value $=0.890)$ difference between the snacking among those who took the three normal school meals and those who took less $\left(\chi^{2}=1.692\right)$. All students were served with more or less the same rations. Though snacking may not affect the attendance to the meals, it might, however affect the quantities of meals consumed as well as consumption of normal school meals. These results agree with reports of similar study in Portugal on trends of food intake in 1987-1999 [25].

Table 12: Snacking and consumption of normal school meals

\begin{tabular}{|cccccccc|}
\hline $\begin{array}{l}\text { Consumption of the 3 } \\
\text { Normal school meals }\end{array}$ & \multicolumn{3}{c}{ Snacking } & & & Total \\
& Yes & $\mathbf{( \% )}$ & No & $\mathbf{( \% )}$ & n & (\%) \\
\hline Yes & 234 & $(68.8)$ & 26 & $(7.6)$ & 260 & $(76.5)$ \\
No & 75 & $(22.1)$ & 5 & $(1.5)$ & 80 & $(23.5)$ \\
\hline Total & $\mathbf{3 0 9}$ & $\mathbf{( 9 0 . 9 )}$ & $\mathbf{3 1}$ & $\mathbf{( 9 . 1 )}$ & $\mathbf{3 4 0}$ & $\mathbf{( 1 0 0 )}$ \\
\hline
\end{tabular}

NB: Percentages is in parenthesis

\subsubsection{Dietary Intake of Protein and Energy by the Students}

\subsubsection{RDAs Percentage Fulfillment of Macronutrients by Gender}

According to Table 13, more than $50 \%$ of the students had an intake of greater than or equal to $100 \%$ RDA fulfillment of all the macronutrients. The major contribution to this intake was the carbohydrates. More males $(32.2 \%)$ than females $(29.1 \%)$ had taken greater than $100 \%$ RDA fulfillment of protein nutrient, while more females $(42.0 \%)$ than males $(32.2 \%)$ had greater than $100 \%$ RDAs fulfillment of energy, carbohydrate (41.9\% females and $35.5 \%$ males), and fat (35.4\% females and $22.6 \%$ males). This is because females did not have access to some protein snacks such as smokies/sausages which were readily available in males' school canteen. Though they could buy milk from their canteen, there was limited time for accessing the canteen, which would probably explain why twice the number of females (25.8\%) than males (12.9\%) had lower RDA \% fulfillment of protein intake comparatively. Again, about $38.7 \%$ had inadequate protein intake with more females $(25.8 \%)$ than males $(12.9 \%)$ having inadequate protein intake. Both males and females each recorded $12.9 \%$ of inadequate intake of energy. Meals in both schools were more or less the same as can be seen TABLE 15. More males $(22.6 \%)$ than females $(19.4 \%)$ had inadequate fat intake. The females were provided with buttered bread during 10 ' O'clock break time and after dinner.

More students had taken $\geq 100 \%$ RDAs for all the macronutrients. Hence, students who had an inadequate intake of all macronutrients were less as compared to those who had $\geq 100 \%$ RDA. In addition, it was noted that more students of the older age (15 to 18 years in senior classes) had inadequate fat intake (42.2\%) as compared to other macronutrients i.e. $25.8 \%$ for energy, $22.6 \%$ for carbohydrates and $38.7 \%$ for proteins. On the other hand, more students $(77.4 \%)$ had taken adequate $(\geq 100 \%)$ RDA for carbohydrates as compared to $74.2 \%$ for energy, $58 \%$ for fat and $61.3 \%$ for proteins. Majority of the students (males $71.4 \%$ and females $53.0 \%$ ) achieved adequate RDA protein fulfillment. Results however show that significantly a higher percentage of females achieved RDA for energy than males. This trend was the same with carbohydrates and fat. But the trend was reversed in protein intake. Results also indicate that significantly a higher percentage of males did not achieve RDA for energy (28.6\%) than females $(23.5 \%)$. This trend was the same with fats. However, significantly a higher percentage of females than males had inadequate RDA achievement with carbohydrate and protein.

Table 13: Distribution of RDA Percentage Fulfillment of Macronutrients by Gender

\begin{tabular}{|c|c|c|c|c|c|c|c|c|}
\hline \multirow{3}{*}{$\begin{array}{l}\text { RDA PERCENT (\%) } \\
\text { FULFILMENT OF } \\
\text { MACRONUTRIENTS }\end{array}$} & \multicolumn{8}{|c|}{ NUTRIENTS } \\
\hline & \multicolumn{2}{|c|}{ ENERGY (\%) } & \multicolumn{2}{|c|}{ CARBOHYDRTE (\%) } & \multicolumn{2}{|c|}{ FAT $(\%)$} & \multicolumn{2}{|c|}{ PROTEIN (\%) } \\
\hline & $\begin{array}{l}\text { Male } \\
\mathrm{n}=14\end{array}$ & $\begin{array}{l}\text { Female } \\
\mathrm{n}=17\end{array}$ & $\begin{array}{l}\text { Male } \\
\mathrm{n}=14\end{array}$ & $\begin{array}{l}\text { Female } \\
\mathrm{n}=17\end{array}$ & $\begin{array}{l}\text { Male } \\
\mathrm{n}=14\end{array}$ & $\begin{array}{l}\text { Female } \\
\mathrm{n}=17\end{array}$ & $\begin{array}{l}\text { Male } \\
\mathrm{n}=14\end{array}$ & $\begin{array}{l}\text { Female } \\
\mathrm{n}=17\end{array}$ \\
\hline $\begin{array}{l}\text { Inadequate } \\
{[\text { Less than }(>) 100 \% \text { RDA }]}\end{array}$ & 28.6 & 23.5 & 21.4 & 23.5 & 50.0 & 35.3 & 28.6 & 47.0 \\
\hline $\begin{array}{l}\text { Adequate [Greater than or equal } \\
\text { to }(\geq) 100 \% \text { RDA] }\end{array}$ & 71.4 & 76.5 & 78.6 & 76.5 & 50.0 & 64.7 & 71.4 & 53.0 \\
\hline Total $\mathbf{N}=\mathbf{3 1}$ & 100 & 100 & 100 & 100 & 100 & 100 & 100 & 100 \\
\hline
\end{tabular}




\subsubsection{Mean Intake of Macronutrients per Day}

Table 14 shows that more males than females had a higher mean intake of carbohydrate $(363.7 \mathrm{~g})$, energy $(2454.1 \mathrm{kcal})$, fat $(79.9 \mathrm{~g})$, and protein $(67.1 \mathrm{~g})$ than females with carbohydrate mean $=351.6 \mathrm{~g}$, energy mean $=2311.2 \mathrm{~g}$, fat mean $=71.5 \mathrm{~g}$ and protein mean $=59.4 \mathrm{~g}$. Males recorded a mean intake of $67.1 \mathrm{~g} \pm 18 \mathrm{SD}$ protein and females recorded a mean intake of $59.4 \pm 5.9$ protein hence an adequate intake of protein. Adolescent females require approximately $0.8 \mathrm{~g} / \mathrm{kg} / \mathrm{day}$ of protein, with an average of $56 \mathrm{~kg}$.This means that their average protein requirement is $44.8 \mathrm{~g}$. It then turns out that females had adequate average protein intake, with a mean intake of $59.4 \mathrm{~g}$. Similarly, males had a mean weight of $51.7 \mathrm{~kg}$ and given a requirement of 1.0 $\mathrm{g} / \mathrm{kg} / \mathrm{day}$, then they had an average requirement of $51.7 \mathrm{~g}$ protein per body weight per day.

Table 14: Mean Intakes of Macronutrients

\begin{tabular}{|lccccrr|}
\hline Nutrient & $\begin{array}{l}\text { Males } \\
\text { Mean }\end{array}$ & (SD) & $\begin{array}{c}\text { Females } \\
\text { Mean }\end{array}$ & (SD) & Mean & $\begin{array}{c}\text { Total } \\
\text { (SD) }\end{array}$ \\
\hline Energy (kcal) & 2454.1 & 689.3 & 2311.2 & 397.7 & 2375.8 & 543.6 \\
Carbohydrate (g) & 363.7 & 76.1 & 351.6 & 53.9 & 357.1 & 64.0 \\
Fat (g) & 79.9 & 38.9 & 71.5 & 19.5 & 75.2 & 29.6 \\
Protein (g) & 67.1 & 18.0 & 59.4 & 5.9 & 62.9 & 13.2 \\
\hline
\end{tabular}

\subsection{Effect of Snacking on Nutrient Adequacy}

Table 15 shows a cross-tabulation done to find out whether snacking had any effect on nutrient adequacy of the students. Most of the students $(70 \%)$ who snacked were found to have taken $\geq 100 \%$ RDAs of energy in the previous 24 hours. Another $56.6 \%$ had taken $\geq 100 \%$ of fat. The $p$-values for all the macronutrients was greater than 0.05 and hence, there was no significant difference between the nutrient adequacy of those who were snacking and those who were not. The study therefore concludes that snacking did not affect nutrient adequacy of the students.

Table 15: Effect of Snacking on Macronutrient Adequacy

\begin{tabular}{|c|c|c|c|c|c|c|}
\hline \multirow{2}{*}{\multicolumn{2}{|c|}{$\begin{array}{l}\text { Snacking } \\
\text { value } \\
(\mathrm{N}=30)\end{array}$}} & \multicolumn{3}{|c|}{ Nutrient adequacy (\% RDA fulfillment) } & \multirow{3}{*}{$\begin{array}{l}\chi^{2} \\
(\mathbf{d f}=2)\end{array}$} & \multirow[t]{3}{*}{$\mathbf{P}-$} \\
\hline & & $\leq \mathbf{1 0 0} \%$ RDA & & $\geq 100 \%$ RDA & & \\
\hline \multicolumn{5}{|l|}{ Energy } & & \\
\hline Yes $\mathrm{n}(\%)$ & 7 & $(23.3)$ & 21 & $(70.0)$ & \multirow{3}{*}{0.712} & \multirow{3}{*}{0.700} \\
\hline No $\mathrm{n}(\%)$ & 1 & $(3.3)$ & 1 & $(3.3)$ & & \\
\hline $\begin{array}{l}\text { Total n=30(\%) } \\
\text { Carbohydrate: }\end{array}$ & 8 & $(26.7)$ & 22 & (73.3) & & \\
\hline$\overline{\text { Yes } \mathrm{n}(\%)}$ & 6 & $(20)$ & 22 & $(73.4)$ & \multirow{3}{*}{0.918} & \multirow{3}{*}{0.632} \\
\hline No $\mathrm{n}(\%)$ & 1 & $(3.3)$ & 1 & $(3.3)$ & & \\
\hline \multicolumn{5}{|c|}{ Protein: } & & \\
\hline Yes $\mathrm{n}(\%)$ & 10 & $(33.3)$ & 18 & $(60.0)$ & \multirow{3}{*}{3.214} & \multirow{3}{*}{0.200} \\
\hline No $\mathrm{n}(\%)$ & 2 & $(6.7)$ & 0 & $(0.0)$ & & \\
\hline Total $n=30(\%)$ & 12 & $(40)$ & 18 & $(60)$ & & \\
\hline \multicolumn{7}{|l|}{ Fat: } \\
\hline Yes n $(\%)$ & 11 & $(36.7)$ & 17 & $(56.6)$ & & \multirow[b]{2}{*}{0.246} \\
\hline No $n(\%)$ & 1 & $(3.3)$ & 1 & (3.3) & 2.802 & \\
\hline Total $\mathbf{n}=\mathbf{3 0}(\%)$ & 12 & (40) & 18 & $(60)$ & & Activate \\
\hline
\end{tabular}

\subsection{Conclusions and practical implications}

\section{Conclusions and Recommendations}

Most of the students were found to snack on junk foods such as crisps, sweets, chapatti, mandazi, masala sticks and carbonated soft drinks, other than healthy snacks. There were no varieties of snacks, in terms of quality and quantities stocked in the males' school canteen. There was no significant difference between snacking among those who consumed three normal school meals and those who took less. Though snacking may not affect consumption of normal school meals, it does affect the quantities of meals consumed.

There was no significant difference between snacking and nutrient adequacy (energy and protein) from dietary intake. Therefore, snacking did not significantly affect the adolescent students' nutrient adequacy and achievement of RDAs for protein, energy, carbohydrates and fats. Practically, snacking is an important part of dietary intake. Hence, the composition of the snacks consumed is important for the total dietary intake, and 
subsequently for the health and wellbeing of the population. It is therefore essential to promote healthy snack options.

\subsection{Recommendations}

Nutrition education should be included in the school curriculum as mandatory subject to help develop healthy, positive eating of snacks patterns that carry through during adolescence to adulthood. This will contribute to their overall healthful daily dietary intake of nutrients and hence academic performance. There is need to strengthen the sale of quality and adequate quantities of affordable snacks as well as promotion of a variety of healthy food stuffs and snacks in the school canteen. These should include a variety of fruits, fresh fruit juices, vegeTABLE snacks, pastries and whole meal bread sold in smaller pieces

There is need to limit unhealthy fat-rich and sugar-rich snacks such as sweets and commercial juices in school canteens. This will ensure that those who opt out of some school meals can have adequate intake of nutrients. There is need to review management of school canteens in terms of quality and quantity of affordable snacks without jeopardizing other school programs as the school canteens are the greatest source of snacks consumed in the schools.

\subsection{Suggestions for further research}

More research need to be done on the effect of snacking on micro-nutrients adequacyb notably iron and calcium; vitamins $\mathrm{A}$ and $\mathrm{C}$ intake by adolescents as their deficiencies can lead to increased fatigue and decreased ability to concentrate and learn thus affecting school and physical performance. Since this study was carried out in public national boarding high schools in Nairobi, a comparative study on the same topic could be done on private boarding high schools in Nairobi County as well as in other boarding high schools in other counties.

\section{Acknowledgement}

Special thanks go to my supervisors Prof. Jasper K. Imungi and Dr. Edith M. Ngatia for their consistent guidance, patience, time, understanding and encouragement. My heartfelt gratitude go to Prof. Jasper K. Imungi, and Dr E.M. Ngatia without whose concern and interest in seeing me complete this dissertation, my joy would not have been complete. Much thanks to my dear husband, Dr. Jackan M. Gutu, for his inspiration, great counsel and moral support; our daughters Grace Njoki and Wanjiru Gutu who kept on reminding me about finishing corrections; for always loving and being there for me as well as being patient enough to see me through this important course of a lifetime. My heartfelt gratitude go to my colleagues J. Malla and P. Gichuhi for standing in for me at work, without whose concern, patience and interest in seeing me complete this course my dream would not have come true. I appreciate and thank the principals, teachers, particularly W. Mutindwa and J. Maina (Deputy Principal) of Nairobi School; R. Saina, the Principal, Kenya High School and L. Mugendi, for their support during data collection; cateresses/caterers, cooks and all students who enthusiastically provided information for this study. Special appreciations and thanks go to Benta Achieng, Jedidah W. K. Stephen Obiro and my Nutrition and Dietetics students for their significant role as Research Assistants.

\section{References}

[1] Bellisle, F., Dalix, A.M., Mennen, L., Galan, P., Hercberg, S., de Castro, J.M., et al. (2003). Contribution of snacks and meals in the diet of French adults: a diet-diary study. Physiology \& Behavior, 183-189, [Pub Med].

[2] World Health Organization, Nutrition in adolescence: Issues and Challenges for the Health Sector. Issues in Adolescent Health and Development, (Geneva, Switzerland: WHO, 2005).

[3] G.M, Wardlaw, Contemporary nutrition: issues and insights, $5^{\text {th }}$ ed. (Boston: MacGraw Hill, 2003)

[4] A.B, Barbara, M.R, Robert, eds., Present knowledge in nutrition ( $8^{\text {th }}$ edition), (Washington, DC: International life Sciences Institute-ILSI Press, 2001), 426-36.

[5] F. Bellisle, Impact of the daily meal pattern on energy balance, Scandinavian Journal of Nutrition, 48, 2004, 114-118.

[6] R.S, Sebastian, J.D, Goldman, and Enns. C, Wilkinson, (2010), Snacking patterns of U.S. Adolescents: What we eat in America.NHANES 2005-2006. Food surveys Research Group Dietary Data Brief NO. 2. (Accessed in September 2010)

[7] R.S, Sebastian, L.E, Cleveland, and J.D, Goldman, Effect of snacking frequency on adolescents' dietary intakes and meeting national recommendations, Journal of Adolescent Health. 42, 2008, 503-511.

[8] D.R, A.N Theresa, and E.O, Carol, Snacking is associated with reduced risk of overweight and reduced abdominal obesity in adolescents: National Health and Nutrition Examination Survey (NHANES), Am Journal of Clinical Nutrition, 92, 1999-2004, $428-35$.

[9] H.A, Guthrie, Introductory Nutrition. th $^{\text {th }} e d$. (St. Louis: times mirror/ mosby college publishing, 1989).

[10] G.J, De Bruijn,S.P, Kremers, H, Schaalma, W. Van Mechelen, and J, Brug, Determinants of adolescent bicycle use for transportation and snacking behavior, Journal of Preventive Medicine, 40, 2005, 658-667.

[11] T.A. Nicklas, S.J. Yang, T Baranowski, I Zakeri, and G Berenson, Eating patterns and obesity in children: The Bogalusa Heart Study, American Journal of Preventive Medicine, 25, 2003, 9-16. [Pub Med].

[12] M.R. Mascarenhas, B.S. Zemel, A.M. Tershakovec, and V.A. Stallings, Adolescence. In: Bowman, B, A., and Russel, R, M. eds. Present knowledge in Nutrition ( $8^{\text {th }}$ edition), (Washington, DC: International life Sciences Institute-ILSI Press, 2001) 426-436.

[13] J.T. Dwyer, Adolescence. In: Ziegler, E.E., Filer, L.J., eds. Present knowledge in nutrition ( $7^{\text {th }}$ edition), (Washington, DC: International life Sciences Institute-ILSI Press, 1996) 404-13 
[14] J.T. Dwyer, M Evans, E.J. Stone, H.A. Feldman, L Lytle, D Hoelscher, C Johnson, M Zive, \& M Yang, Adolescents' eating patterns influence their nutrient intakes, Journal of American Dieticians Association.101, 2001,798-802.Doi:10.1016/S00028223(01)00198-5.

[15] A.T. Cross, D Babicz, and L.F. Cushman, L.F. (1994). Snacking patterns among 1,800 adults and children, Journal of American Dietecians Assoc. 94, 1994, 1398-1403.

[16] N.C. Howarth, T.T.K. Huang, S.B. Roberts, B.H. Lin, and M.A. McCrory, Eating patterns and dietary composition in relation to BMI in younger and older adults, International Journal of Obesity, 31,2007, 675-684.

[17] Institute of Medicine, Food and Nutrition Board (2000).Dietary Reference Intakes: Applications in Dietary Assessment.Washington, DC: National Academy Press.

[18] A Fisher, J Lang, and J Stockel, Handbook for family planning operation research design, pp 32 -34. (New York: The Population Council, 1991)

[19] E. M. Ngatia, Nutritional status of school children aged 6-17 years in Nairobi: Child Health.(Nairobi, Kenya: Ministry of Health, 2006)

[20] G.S. Eshiwani, Eeducation in Kenya since independence.(Nairobi: East African Publishers,1993).

[21] O. M. Mugenda, and A G, Mugenda, Research methods: quantitative and qualitative approaches (Nairobi, Kenya: ACTS Press. 1999).

[22] R S. Gibson, Principles of Nutrition Assessment, $2^{\text {nd }}$ ed. (New York, USA: Oxford University Press, 2005).

[23] Kenya National Bureau of Statistics (KNBS) and ICF Macro. Kenya Demographic and Health Survey 2008-09. (Calverton, Maryland: KNBS and ICF Macro. 2010).

[24] J S. Hampl, C.L.B. Heaton, and C .A. Taylor, Snacking patterns influence energy and nutrient intakes but not body mass index, Journal of Human Nutrition Diet, 16,2003, 3-11. doi: 10.1046/j.1365-277X.2003.00417.x.

[25] P Marques-Vidal, P Ravasco, C M. Dias, and M. E Camilo, Trends of food intake in Portugal, 1987-1999: results from the National Health Surveys, European Journal of Clinical Nutrition, 60,2006, 1414-1422. 